\title{
Unaccusativity and the syntax of imperatives in East Circassian
}

\author{
Ksenia Ershova*
}

\begin{abstract}
This paper presents novel evidence for the syntactic distinction between unergative and unaccusative verbs in East Circassian (or Kabardian). The evidence concerns a particular strategy of forming imperatives - simultaneous causativization and reflexivization - which is only applicable to unaccusative predicates. I argue that this type of imperative involves the promotion of the internal argument to the a higher position through the use of the causative morpheme which has been grammaticalized to mark imperative mood. The observed patterns suggest that imperative mood, while generally associated with the CP-layer, must be sensitive to the structure of $v \mathrm{P}$.
\end{abstract}

Keywords. unaccusativity; imperative mood; causative; East Circassian; Kabardian; Northwest Caucasian

1. Introduction. This paper addresses the syntactic distinction between unergative and unaccusative verbs in East Circassian, a language that has not been previously observed to draw such a divide. The evidence for unaccusativity comes from an unlikely source - the morphology of imperative mood. In particular, unaccusative verbs may form a special type of imperative that is unavailable for unergative verbs. This imperative form involves the transitivization of the verb via a synthetic causative morpheme and reflexivization of the causee. An example of this imperative form can be seen in $(1)^{1}-$ I will refer to this form as the reflexive causative strategy of imperative formation throughout this paper.

$$
\text { z-o-mว-вe-g }{ }^{\mathrm{w}} \partial \mathrm{b} \hat{\mathbf{z}}
$$

\section{REFL.ABS-2SG.ERG-NEG-CAUS-be.angry}

'Don't be angry (lit. don't make yourself angry)'

Importantly, despite both the causative and reflexive morphemes being highly productive in the language, this particular construction is only available in the imperative mood. I argue that the limitation of this form to unaccusative verbs is due to the selectional properties of the imperative head involved: (i) it selects VP as its complement and licenses an external argument specifier via ergative case assignment, but (ii) it does not introduce a new $\theta$-role. This combination of properties necessitates the recycling of the internal argument of an unaccusative verb through reflexivization and restricts the use of this head to unaccusative predicates. The sensitivity of an imperative mood head to the internal structure of VP in East Circassian calls for locality between the imperative head and VP, thus challenging the longstanding assumption that imperative force is introduced in the periphery of CP.

*This talk is based on data collected in the village Khodz (Republic of Adygea, Russia) during an expedition organized by the Higher School of Economics and the Russian State University for the Humanities in 2016. The data comes from the Kuban dialect of East Circassian, unless otherwise noted. I am deeply indebted to the speakers of East Circassian for their generous help. I am thankful to Yury Lander for guidance in the field, and to Karlos Arregi for continuous feedback and support. I am also thankful to the audience of LSA 91. All mistakes and shortcomings are solely mine. Author's affiliation: University of Chicago (kershova@uchicago.edu).

${ }^{1}$ Abbreviations: ABS - absolutive; CAUS - causative; COM - comitative; DEM - demonstrative; DIR - directive/inverse; DYN - present tense (dynamic verbs); ERG - ergative; LOC - locative; NEG - negation; PL - plural; PST past tense; RE - refactive; REFL - reflexive; PP - complement of postposition; SG - singular. 
East Circassian is uniformly ergative in both case assignment and verbal agreement, drawing no distinction between intransitive verbs with an agentive or patientive $\theta$-role. Thus, both an unergative verb like $d e k^{w} e$ - 'get married' / 'go with s.o.' (2) and an unaccusative verb like $\hat{s} t \partial-$ 'freeze' (3) take an absolutive subject, marked here with the absolutive case marker $-r$.

\section{(2) pŝâ̂e-r $\varnothing-d e-k^{w}-a$}

girl-ABS 3 ABS-COM-go-PST

'The girl got married (lit. went with s.o.).'
(3) psə-r $\quad$ - $\mathrm{s} t-\mathrm{a}$

water-ABS 3 ABS-freeze-PST

'The water froze.'

Well-known diagnostics for unaccusativity such as resultative constructions have yet to be tested in the language ${ }^{2}$, while other standard diagnostics such as auxiliary selection and impersonal passive constructions (Levin \& Rappoport Hovav 1994) are not applicable in East Circassian. Thus, the imperative construction presented here is the only documented diagnostic for syntactic unaccusativity in the language.

The remainder of the paper is structured as follows. Section 2 presents the reflexive causative strategy of marking imperative mood and discusses its distribution. Section 3 accounts for the restrictions on the distribution of this construction, arguing that the selectional features of the imperative head involved limit its usage to unaccusative predicates. Section 4 discusses the implications of the presented data for our understanding of imperative syntax. Section 5 concludes.

2. The pattern. This section outlines the distributional properties of the reflexive causative imperative form. I show that the use of this form is restricted to intransitive predicates that entail affectedness on the part of their sole argument, i.e. a class of predicates that have been documented to behave as unaccusative verbs cross-linguistically (Arkadiev 2008).

2.1. MoRPhOlOGY OF IMPERATIVE MOOD. In East Circassian, imperative mood is characterized with a particular morphological profile: (i) the lack of overt TAM morphology; (ii) the omission of second person singular agreement morphology in the absence of negation; (iii) prefixal negation (as opposed to suffixal negation in the indicative mood) (Kumakhov 2006). Examples of imperative forms can be seen below. The imperative form of $\dot{q}$ jow $\partial v e$ - 'stand' with a singular second person addressee (4a) is contrasted to the same verb in the indicative mood (4b): in the former case overt agreement with the subject is impossible, in the latter case it is obligatory. Subject agreement on the imperative form is overt if the subject is plural (4c), or in the presence of negation (5a). Note also that negation in the imperative mood is expressed via the prefix mə- (4c), as opposed to suffixal negation $-\dot{q} \partial m$ in the indicative mood (5b).

a. sjawəž $\quad(* w \partial-) \dot{q}-j \partial-w \partial v e$

1SG.PP+after (*2SG.ABS-)DIR-LOC-stand

'Stand behind me!'

b. we sjawəž $*($ wə-) $\dot{q}-j ə-w \partial v-a$

you 1SG.PP+after 2SG.ABS-DIR-LOC-stand-PST

'You stood behind me.'

c. sjawəž $\quad$ fə- $\dot{\mathrm{q}}-\mathrm{j} \partial-w \partial v e$

1SG.PP+after 2PL.ABS-DIR-LOC-stand

'You(pl) stand behind me!'

\footnotetext{
${ }^{2}$ For a brief description of resultatives in East Circassian see Klimenchenko 2014).
} 
a. mə?erəse $\emptyset-*(\mathbf{w} \boldsymbol{-}-)$ mə-š’ $x$ apple 3ABS-2SG.ERG-NEG-eat

'Don't eat the apple.'

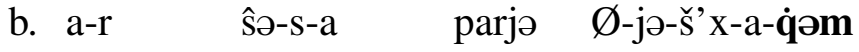

DEM-ABS LOC-sit-PST nothing 3ABS-3SG.ERG-eat-PST-NEG

'He sat and didn't eat anything.'

2.2. REFLEXIVE CAUSATIVE STRATEGY. In addition to the unmarked imperative form described above, for a number of intransitive verbs the imperative mood may be expressed via the use of the causative morpheme $\mathbf{s e}$-. In this case the second person subject is promoted to the position of the ergative causer, while the causee is expressed as the absolutive direct object that is coindexed with the causer and thus marked with the reflexive morpheme $z \partial-(6 \mathrm{~b})$. For the surveyed verbs, this form is never obligatory and exists alongside the regular unmarked imperative form. Examples of verbs that may form this type of imperative are $g^{W} \partial b \hat{z} \partial-$ 'be angry' and $\chi^{W} \partial z$ ' $\partial-$ 'get well (lit. become again)': in (6a) and (7a) we can see the regular unmarked imperative form; this is contrasted with (6b) and (7b), where a causative morpheme pheme $z$ - is used to mark the causee in the absolutive position. The unmarked form and the reflexive causative form are interpreted as synonymous by speakers and are deemed acceptable in identical contexts.

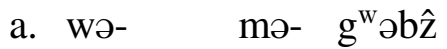

2SG.ABS- NEG- be.angry

'Don't be angry.'

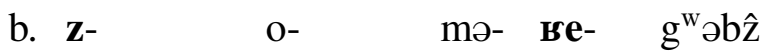

REFL.ABS- 2SG.ERG- NEG- CAUS- be.angry

CAUSEE $_{i} \quad$ CAUSER $_{i}$

'Don't be angry (lit. don't make yourself angry).'

(7) a. psənč̣'a-? ${ }^{\mathrm{w}} \chi^{\mathrm{w}} \partial-\mathrm{z}$ '

fast-very become-RE

'Get better (lit. become again) soon!'

b. psənç̌'a- ${ }^{\mathrm{w}}$ zo-re- $\chi^{\mathrm{w}}$ ว-ž'

fast-very REFL.ABS-CAUS-become-RE

'Get better (lit. make yourself become again) soon!'

Besides the addition of the causative and reflexive morphology, the morphosyntactic properties of this form are identical to the unmarked imperative: the same prefixal negation mə- is used (6b), and second person singular subject agreement is dropped in non-negated forms (7b).

Notably, this strategy is not available for all intransitive predicates. For example, the unergative verbs $g^{W} e$ - 'yell' and $\dot{q} e f e$ - 'dance' are incompatible with the reflexive causative imperative form (8a), (9a); only the unmarked imperative form may be used in this case (8b), (9b). 
a. $\quad * \mathbf{z}-\mathrm{o}-\mathrm{m}$ - $\mathbf{-} \mathbf{a}-\mathrm{g}^{\mathrm{w}} \mathrm{e}$

REFL.ABS-2SG.ERG-NEG-CAUS-yell

Expected: 'Don't yell (lit. don't make yourself yell). ${ }^{3}$

b. wə-mว-gwe

2SG.ABS-NEG-yell

'Don't yell.'

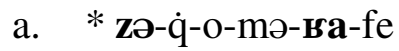

REFL.ABS-DIR-2SG.ERG-NEG-CAUS-dance

Expected: 'Don't dance (lit. don't make yourself dance).'

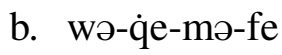

2SG.ABS-DIR-NEG-dance

'Don't dance.'

Kumakhov (2006:223) notes that this type of imperative is limited to stative denominal predicates such as hezər 'ready' (10); were that the case, it could be a potential explanation of the impossibility of this form with a verb like $g^{w} e$ - 'yell' or $\dot{q} e f e$ - 'dance' in (8a) and (9a), which are both dynamic predicates.

(10) zə--Be-hezər

REFL.ABS-CAUS-ready

'Get ready (lit. make yourself ready)!' (Standard East Circassian; Kumakhov 2006:223)

However, my data suggests that this form is not in fact restricted to stative predicates. The trademark property of dynamic predicates in East Circassian is prefixal present tense marking me(word-initially) / $o$ - (word-internally) (Kumakhov 2006:158); based on this criterion several of the predicates that may form the reflexive causative imperative are in fact classified as dynamic. For example, the verbs səme ̌̌ $e$ - 'be sick' and $\dot{q} j e x^{W} e x^{w} \partial-$ 'fall' may form the reflexive causative imperative (11), (12) despite the fact that they both take the dynamic present tense prefix me-/o(13)-(14).

(11) z-o-mə-вe-səmaže

REFL.ABS-2SG.ERG-NEG-CAUS-be.sick

'Don't get sick (lit. don't make yourself sick).'

zə- $\dot{\mathrm{q}}-\mathrm{O}-\mathrm{m} \partial-\mathbf{B e}-\mathrm{X}^{\mathrm{w}} \mathrm{ex}^{\mathrm{w}}$

REFL.ABS-DIR-2SG.ERG-NEG-CAUS-fall

'Don't fall (lit. don't make yourself fall).'

${ }^{3}$ The causative morpheme is expected to take the form $\mathbf{s a}$ - here and in the following example due to a regular phonological alternation: /e/ $\rightarrow / \mathrm{a} /$ in the penultimate syllable of a stem that ends in the sequence CeCe (see e.g. Kumakhov 2006:58-59; Bagov et al. 1970:32-33). This alternation within the causative morpheme ве- can be seen below:

(1) haq $\dot{q}^{w} \partial \hat{s} ə \dot{q}^{w} \partial-x e-r$ mə-thaṣ̂ž -a-we $\dot{q} e-v-m ə-\mathbf{s a}-n e$

dishes-PL-ABS NEG-wash-PST-ADV DIR-2PL.ERG-NEG-CAUS-stay

'Don't leave (lit. make stay) the dishes unwashed.' 
(13)

zeç’ exerjə Ø-me-səmaže

all.PL.ABS 3ABS-DYN-be.sick

'Everyone is sick.'

(14) $\varnothing-\dot{q}-\mathbf{o}-x^{\mathrm{w}} \mathrm{ex}{ }^{\mathrm{w}}$

3 ABS-DIR-DYN-fall

'S/he is falling.'

Thus, the stative-dynamic distinction is not the relevant criterion for defining the distribution of the reflexive causative imperative. Rather, the generalization is that this form may only be used with unaccusative verbs. The distribution of the reflexive causative is summarized in (15): the left column lists the verbs for which this form is available; the right column lists verbs which may not form this type of imperative.

\begin{tabular}{|c|c|c|}
\hline \multicolumn{2}{|c|}{$\checkmark$ Reflexive Causative: } & *REFLEXIVE CAUSATIVE: \\
\hline š’’ne- & 'to be afraid' & Ž’jejə- 'sleep' \\
\hline$\chi^{\mathrm{w}} \partial_{-}^{-}$ & 'become' & š’əsə- 'sit' \\
\hline$\chi^{\mathrm{w}} \partial \check{z ̌}^{\prime} \partial-$ & 'get well' & pse $\lambda$ e- 'speak' \\
\hline $\mathrm{B}^{\mathrm{w}}$ əbẑzว- & 'be angry' & ‘yell' \\
\hline pŝente- & 'sweat' & 'dance' \\
\hline səmeže- & 'be sick' & \\
\hline ŝtว- & 'freeze' & \\
\hline $\begin{array}{l}\dot{\mathrm{q} j} \mathrm{je} \chi^{\mathrm{w}} \mathrm{ex}^{\mathrm{w}}{ }^{-}- \\
\gamma^{\mathrm{w}} \text { ebeŝe- }\end{array}$ & $\begin{array}{l}\text { 'fall' } \\
\text { 'overheat' }\end{array}$ & \\
\hline
\end{tabular}

As can be seen from the list of verbs presented in (15), the verbs that form the reflexive causative imperative all semantically entail affectedness of the individual they are predicated over, i.e. they can be classified as affective or patientive. In many languages this class of verbs forms a uniform morphosyntactic class in terms of e.g. subject case marking (Arkadiev 2008). In accordance with the widely assumed Unaccusative Hypothesis (first introduced by Perlmutter 1978), the sole argument of such verbs originates as an internal argument within VP (16); these verbs are generally classified as unaccusative. Unaccusative verbs are opposed to agentive, or unergative, verbs, which select for an external argument in a higher position - in Minimalist terms - in Spec, $v \mathrm{P}$ (17); see e.g. Harley (2011). Thus, the reflexive causative imperative is only possible for unaccusative verbs, i.e. verbs which take a sole internal argument.

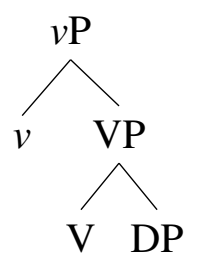

(17)

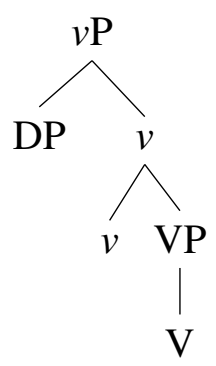

It is important to note that outside of this construction, both causative and reflexive morphology is productively used with all types of verbs. For example, in (18) we can see the causative 
morpheme form the reflexive causative imperative.

nane nenawə-r $\varnothing$-jə-ве-ž’jej-a

grandmother child-ABS 3ABS-3SG.ERG-CAUS-sleep-PST

'The grandmother put the child to sleep.' (Rochant 2015)

In (19) we can see the use of the reflexive morpheme zə- to mark the absolutive object of the three place predicate $\hat{s} \partial j j e$ - 'to shelter s.o. (ABS) from smth (IO)'.

?af̣ə-m zə-Ø-ŝ̀-v-zje

sweet-OBL REFL.ABS-3SG.IO-LOC-2PL.ERG-shelter

'Give up (lit. shelter yourself from) sweets!'

However, despite the widespread use of both causative and reflexive morphology, the two are not productively combinable as in the reflexive causative imperative form. In particular, the coindexation of the causer with the causee in a synthetic causative is not acceptable, even for the class of unaccusative verbs listed in (15). For example, while the verb $g^{W} \partial b \hat{z} \partial-$ 'be angry' may form the reflexive causative imperative (6b), this same form (with the causee and causer coindexed via reflexivization) cannot be used in the indicative mood (20a). Importantly, the use of the causative morpheme is perfectly acceptable in the absence of a binding relationship between the causer and causee, as can be seen in (20b), where the absolutive causee is referenced on the verb with regular third person morphology and is interpreted as non-coreferent with the causer.
a. ?? abə
Z-
jə-
ве- $\quad g^{\mathrm{w}}$ əb̂े $-\mathrm{a}$
DEM.OBL REFL.ABS- 3SG.ERG- CAUS- be.angry -PST

$$
\text { CAUSEE }_{i} \quad \text { CAUSER }_{i}
$$

'S/he got angry (lit. s/he ${ }_{i}$ made him/herself ${ }_{i}$ angry).'
b. abə
$\varnothing-$
jə-
se- $\quad g^{\mathrm{w}} \partial b \hat{z} \quad-\mathrm{a}$
DEM.OBL 3ABS- 3 SG.ERG- CAUS- be.angry -PST
CAUSEE $_{j} / *_{i}$ CAUSER $_{i}$
'S/he $\mathrm{i}_{\mathrm{i}}$ angered him/her $\mathrm{h}_{\mathrm{j} / \mathrm{i}}$,

Thus, the reflexive causative construction, i.e. the use of the causative morpheme $s e$ - to introduce a causer that is coreferent with the causee, is only possible in the imperative mood. This leads us to conclude that the reflexive causative form is a strategy of marking imperative mood for unaccusative predicates.

To conclude this section, the reflexive causative form is acceptable (i) only in the imperative mood and (ii) only with unaccusative verbs. In the following section I propose an analysis that accounts for these two restrictions: the causative morpheme in this construction is in fact the spellout of the functional head responsible for imperative formation, and its distributional restrictions are a consequence of its selectional properties.

3. Unaccusative imperative: an analysis. I argue that the distributional restrictions of the reflexive causative imperative form are derived from the semantic and syntactic properties of the morpheme ве-. In particular, the causative morpheme ве- in this construction has grammaticalized to mark imperative mood and is thus stripped of its causative semantics; consequently, it 
does not involve the introduction of an agentive $\theta$-role. On the other hand, this head has retained its causative syntax: it is a $v^{0}$ head that assigns ergative case to its specifier. The restriction to unaccusative verbs is a consequence of the fact that this head selects for VP, combined with the two properties listed above: the lack of agentive semantics and presence of external-argument licensing syntax. In particular, since internal argument within VP. Unergative predicates are then incompatible with this head due to the lack of an internal argument.

3.1. - ве IS AN IMPERATIVE HEAD. As we saw in section 2, the reflexive causative construction is only used in the imperative mood - outside of this context, the coindexation of the causer and causee of a causativized predicate via reflexivization is unacceptable. This raises two questions: (i) why is the causative reflexive construction unacceptable in non-imperative contexts, and (ii) why is this construction acceptable in the imperative mood? I propose the following answer: the coindexation of the causer and causee in a causative construction is anomalous due to the semantics of the causative head; in the reflexive causative construction, on the other hand, the causative

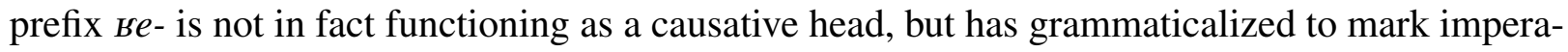
tive mood.

According to Pylkkänen (2008), the primary function of a causative functional projection Cause $^{0}$ is to introduce an additional event of causation. Since the causative morpheme in East Circassian always involves the introduction of an ergative causer, this head is bundled together with the external argument licensing Voice ${ }^{0} / v^{0}$ projection. Thus, in its causative use, the morpheme se-fulfills two functions: (i) the introduction of an event of causation and (ii) the introduction of an agentive $\theta$-role relating to this event (21).

CAusative se $_{1-}:$ Cause $^{0}+v^{0}$

a. Cause $^{0}$ : introduces an event of causation

b. $v^{0}$ : introduces an external $\theta$-role for the causer

Following Legate's (2008) analysis of ergative case as inherent, I assume that ergative case in East Circassian is assigned to the external argument by the head that introduces it, i.e. $v^{0}$. This head is also the locus of $\phi$-agreement with the ergative DP, which is in most cases exponed overtly on the predicate (see e.g. (20b)). In a causative construction, then, the syntactic job of the causative head $\mathrm{se}_{1}$ - is to license the external argument via ergative case assignment and agree with this argument in $\phi$-features (22).

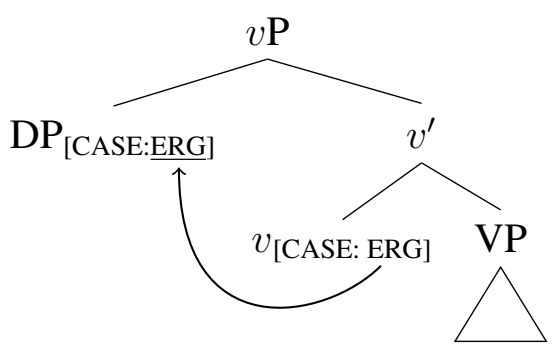

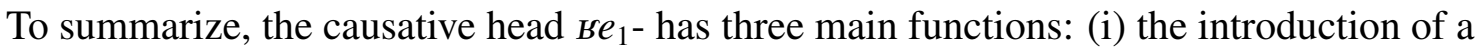
causing event, (ii) the introduction of an agentive $\theta$-role for the causer, and (iii) ergative case assignment and agreement in $\phi$-features with its specifier. 
The reflexive causative imperative form, unlike a regular causative construction, does not carry any clear causative semantics - speakers generally use these forms interchangeably with the unmarked imperative and cannot readily identify any difference in meaning. I propose that the reason for this lies in the fact that the marker $b e$ - in this construction has in fact been bleached of causative semantics, and has come to instead denote an imperative mood head (23). ${ }^{4}$

IMPERATIVE $\mathrm{Be}_{2^{-}}=\operatorname{IMP}^{0}($ Imperative operator $)$

While there are not many mentions of a grammaticalization path from causation to imperative mood, functional motivations for such a path have been noted. In particular, Gusev (2005) argues that imperative constructions are a type of causative construction - a performative one. Subsuming imperative mood under the class of causative constructions is motivated by the fact that the functional role of an imperative speech act is to "cause an event to be realized" (Gusev 2005:16). ${ }^{5}$ It is also worth noting that causative morphology is cross-linguistically often used to mark hortative ( $\left(1^{\text {st }}\right.$ person imperative) mood - a subtype of imperative mood (Xrakovskij 2001).

Semantically, then, this form has nothing in common with the homophonous causative head described in (21): it does not introduce a causing event, nor does it assign an agentive $\theta$-role. The difference in distribution between this form and the regular causative head then stems out of this difference in semantics: in particular, the introduction of a causer that is coindexed with the causee is semantically anomalous in a causative construction. The source of this anomaly is not fully clear, although it is likely to stem out of the particular type of causation the causative head denotes. ${ }^{6}$ This ban on coreference between the external and internal argument (corresponding to the causer and causee respectively for the regular causative construction) is absent for the imperative $\mathrm{Be}_{2}$ - simply because this form does not carry the causative or agentive semantics of the regular causative head.

3.2. Imperative be- ASSIGNS ERGative CASE. Note that, despite the lack of causative semantics, imperative $\mathrm{Be}_{2}$ - morphosyntactically resembles a regular causative head: it appears to increase the valency of the verb it attaches to by introducing an ergative external argument; the $\phi$-features of this external argument are exponed on the predicate via regular ergative agreement. Thus, the unmarked imperative form of an intransitive verb like $p$ șențe- 'sweat' licenses just a single internal argument (24a), while the reflexive causative counterpart licenses two arguments: the internal one and an external argument, which triggers $2^{\text {nd }}$ person singular agreement on the predicate $(24 b)$.

\section{a. wə- mə- pṣ̂ențe-ž' \\ 2SG.ABS- NEG- sweat-RE \\ IntArg}

'Don't get sweaty.'

${ }^{4}$ I do not commit myself here to a particular analysis of imperative semantics; see e.g. Condoravdi \& Lauer (2012); Kaufmann (2012); Portner (2016) for various approaches.

${ }^{5}$ As Gusev (2005) points out, this interpretation of imperatives allows for usages other than demands and orders, such as invitations, absent wishes, etc., since regular causative constructions often express various types of weak or indirect causation (see e.g. Comrie 1989:171-174).

${ }^{6}$ See Rochant 2015 for a survey of the semantic functions of $\mathbf{~} е$ - in the Kuban dialect; see also Letuchiy 2009 for a detailed description of the causative construction in the related language West Circassian. 
b. Z- $\quad$ o- mə- pṣ̂ente- ž

REFL.ABS- 2SG.ERG- NEG- sweat-RE

IntArg +ExtArg

'Don't get sweaty (lit. don't make yourself sweat).'

An important property of this construction, however, is the coreference relation between the core internal argument and the external one that is licensed by the imperative $\mathrm{se}_{2}{ }^{-}$. Thus, while syntactically there are two DPs, both of which are assigned distinct case values (the internal argument - absolutive case, the external one - ergative case), semantically they refer to a single participant. Thus, while imperative $\mathrm{Be}_{2}$ - assigns ergative case, it does not introduce a new participant, but merely assigns it to the one that is already present in the structure. The reason for this unusual behavior is that, despite the shift in semantics, the imperative $\boldsymbol{s} \boldsymbol{e}_{2}$ - is syntactically still $v^{0}$, i.e. it has retained the syntactic properties of the regular causative head $\mathrm{se}_{1^{-}}-$in particular, the ability to assign ergative case to its specifier and agree with its specifier in $\phi$-features. Thus, the imperative $\mathrm{He}_{2}$ - is merged into the structure above the unaccusative VP and triggers the raising of the internal argument to its specifier position for ergative case assignment and $\phi$-agreement (25).

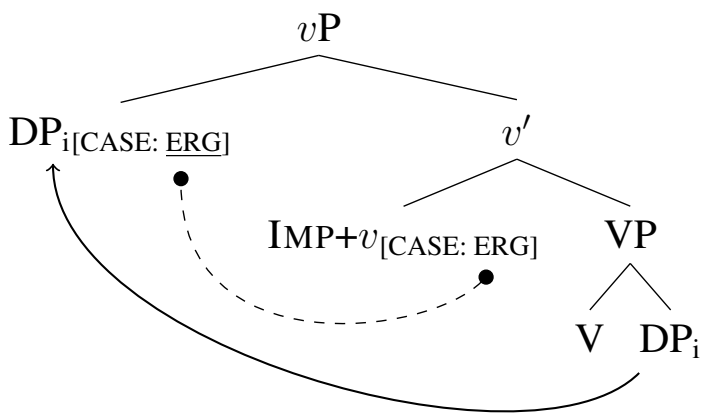

At first glance, such a divorce between inherent case assignment and $\theta$-role licensing is problematic, given that inherent case is defined as "inherently associated with certain $\theta$-positions" (Woolford 2006:112). However, despite lacking a semantic $\theta$-role, the position that is assigned

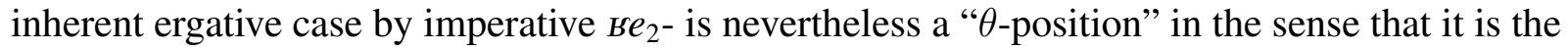
specifier of $v^{0}-$ a functional head that is generally responsible for the $\theta$-role of the external argument.

3.3. REFLEXIVIZATION AS REPAIR. We have established that the reflexive causative imperative involves the use of an imperative head which is equivalent phonologically and syntactically to the causative head $\mathrm{se}_{1^{-}}$, but is semantically distinct from it in that it does not introduce semantics of causation, but rather marks imperative mood. The last ingredient to the reflexive causative is deriving the reflexivization of the internal argument. Since the movement of the internal argument to Spec, $v \mathrm{P}$ is very local - within the boundaries of $v \mathrm{P}$ - the reflexivization of the lower copy can be seen as a repair of movement that is too local, which is a violation of the Anti-Locality Constraint (Grohmann 2003). This constraint states that a movement chain must be sufficiently long, in particular, a moved constituent must not land within the same syntactic domain as its lower copy. The relevant syntactic domains are roughly equivalent to phases - in Grohmann's (2003) terms they are called Prolific Domains. $v \mathrm{P}$ is such a domain: the internal argument in a reflexive causative construction is raised to a position within $v \mathrm{P}$, giving rise to an Anti-Locality violation, which is then repaired via reflexivization. 
3.4. INTERIM SUMMARY. To summarize this section, the reflexive causative imperative is formed via the use of the imperative ${e_{2}-}^{-}$, a functional head that has grammaticalized from the corresponding causative morpheme to mark imperative mood. This head has lost causative semantics and thus does not license an external $\theta$-role. It has, however, retained the syntax of causative $v^{0}$ in that it enters and agreement relationship with and assigns ergative case to its specifier. In order to assign case, this head triggers the raising of the internal argument from within VP to its specifier. This brings about a violation of the Anti-Locality Constraint and thus gives rise to reflexivization of the lower copy.

This analysis explains the restriction of this construction to the imperative mood and the lack of causative semantics in this type of imperative, as well as presents a basis for the reflexivization pattern. The following section outlines how the analysis proposed in this section can account for the restriction of the reflexive causative strategy to unaccusative verbs.

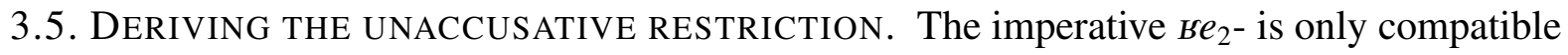
with unaccusative predicates, i.e. predicates with a sole internal argument, due to its selectional properties. In particular, this imperative head selects for VP. Combined with the case-assigning

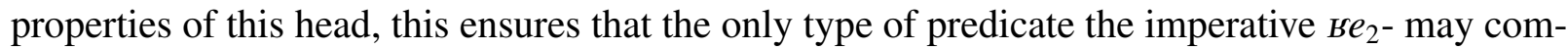
bine with is one with an internal argument within VP, but no external argument, i.e. an unaccusative predicate. Below I outline why the imperative $\boldsymbol{s} e_{2}$ - is incompatible with (1) unergative verbs and (2) transitive verbs.

1. * IMPERATIVE $\boldsymbol{B}_{2} \mathbf{2}^{-}+$UNERGATIVE VERBS:

The imperative $\boldsymbol{~} \boldsymbol{~}_{2}$ - cannot combine with an unergative VP, because this type of constituent does not contain an internal argument. The lack of an internal argument in VP means that there is no DP within this projection to assign ergative case to, since the imperative $-\mathrm{Be}_{2}$ does not license a $\theta$-role of its own - the constructed $v \mathrm{P}$ then lacks a core DP whatsoever. We can see what the hypothetical structure of imperative ве $_{2}-+\check{z}$ 'jejo- 'sleep' would look

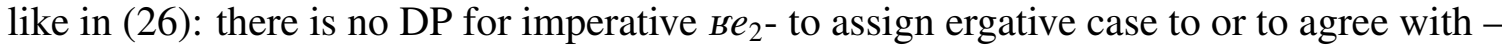
such a derivation would fail to converge.

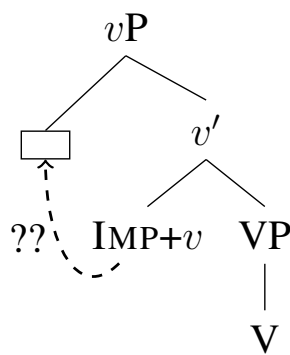

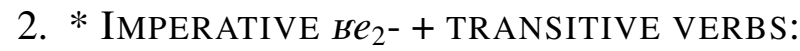

The imperative $\mathrm{Be}_{2}$ - is incompatible with transitive VP for the same reason why transitive verbs cannot generally be used in the absence of an external $\theta$-role, either overtly expressed or existentially bound, as in passives. ${ }^{7}$ Given the decompositional approach to argument structure in Minimalism, where the external argument is introduced outside of VP, it is not

${ }^{7}$ On the status of external arguments in passives see Roeper 1987; Sichel 2009; Landau 2010; Kiparsky 2013; Legate 2014, inter alia. 
fully clear how to structurally implement this constraint, but it is considerably more general than just a constraint on the combinatory properties of imperative $\mathrm{Be}_{2^{-}}$: transitive verbs may generally only be used in the presence of an external $\theta$-role. A simple implementation of this constraint would be to simply specify the selectional properties of imperative $\mathrm{se}_{2}$ - so that it only selects for a VP headed by an unaccusative predicate, i.e. one that is generally not combinable with an external argument.

To summarize, imperative $\mathrm{se}_{2}$ - is a type of ergative-assigning $v^{0}$ which selects for a VP with an internal argument. This VP must be headed by a predicate that does not need to be combined with an external argument. These selectional restrictions ensure that the imperative $\mathrm{Be}_{2}-$ may only combine with unaccusative predicates.

4. Implications. The existence of an imperative head like $\boldsymbol{B e}_{2}$ - has long-reaching implications for the theory of imperative syntax generally. In particular, within accounts that assume that imperative mood is represented in the syntactic architecture, the projection responsible for this semantic component is expected to merge high in the clausal periphery (see e.g. Rivero \& Terzi 1995; Rizzi 1997; Han 1998; Zeijlstra 2006). The reason for this lies in the standard assumptions

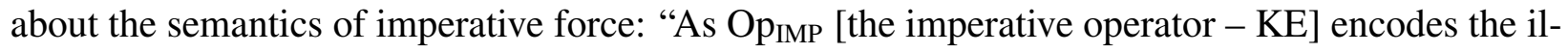
locutionary force rather than the propositional content of the sentence, it cannot be located below other functional projections" (Zeijlstra 2006:415). What this means is that operators like propositional negation cannot take scope over imperative force, i.e. a negative imperative sentence like (27a) can only be rephrased as (27b), with negation taking lower scope than directive force (expressed here as 'I request/order that $X$ '), but not as (27c), where negation takes scope over the directive force.
a. Don't go!
b. $\approx$ [IMP I request/order that [NEG you do not go.]]
c. $\neq$ [NEG I do not [IMP request that you go.]]
IMP $>$ NEG
*NEG > IMP

The imperative head $\mathrm{Be}_{2^{-}}$, on the other hand, must select for an unaccusative VP and thus merge very low - significantly lower than NegP, where negation is assumed to be introduced (see e.g. Zanuttini 1997; Giannakidou 1998). Thus, the reflexive causative imperative construction provides a challenge for the syntax-semantics interface: a functional head must be merged low, but interpreted high.

This type of conflict at the syntax-semantics interface, however, is a well-attested one. Examples of such phenomena include Quantifier Raising ${ }^{8}$ : quantifiers are assumed to covertly raise (syntactically or at LF) in order to take scope over syntactically superior DPs and operators such as negation. Another domain where such a mismatch has been observed is comparative constructions: degree phrases have been argued to undergo covert extraposition in order to achieve the proper scope configuration (see e.g. Heim 2000).

This leads us to conclude, following Zanuttini et al. (2012); Portner (2016), that when it comes to imperative force, the mapping from syntax to semantics need not be a direct one, i.e. imperative force need not be interpreted in the position where it is syntactically introduced. The particular implementation of this remains undetermined: the imperative head may raise covertly to take wide scope, or perhaps illocutionary force is imposed on the utterance pragmatically,

\footnotetext{
${ }^{8}$ See e.g. Abe 2017 for an overview of the phenomenon and existing approaches.
} 
rather than through propositional semantics, as argued e.g. by Condoravdi \& Lauer (2012). I leave the resolution of this question to further research.

5. Conclusion. The reflexive causative strategy of forming imperatives in East Circassian is only available for unaccusative predicates. This strategy involves the use of an imperative head that has grammaticalized from the causative marker ве-. In the process of grammaticalization, this head has shifted semantically from introducing a causing event and external $\theta$-role to marking imperative mood. Syntactically, on the other hand, this imperative head has retained the caseassigning and agreement properties of the regular causative marker. This leads to an otherwise unacceptable coreference relation between the causer (ergative case-assigned DP) and causee (base position of the internal argument in VP). This imperative head is compatible only with unaccusative predicates due to the fact that (i) it selects for VP and (ii) this VP must contain a DP that is eligible for ergative case assignment.

This paper provides empirical support for the syntactic distinction between unergative and unaccusative verbs in East Circassian. Additionally, the sensitivity of an imperative mood marker to the internal structure of VP, namely the presence or absence of an internal argument, requires a low merge site for this imperative head, thus challenging the assumption that imperative force is introduced in the clausal periphery.

\section{References}

Abe, Jun. 2017. Minimalist syntax for quantifier raising, topicalization and focus movement: A search and float approach for internal merge. Springer. doi:10.1007/978-3-319-47304-8.

Arkadiev, Peter. 2008. Thematic roles, event structure, and argument encoding. In Mark Donohue \& Søren Wichmann (eds.), The typology of semantic alignment, 101-117. OUP. https:/doi.org/10.1093/acprof:oso/9780199238385.003.0004.

Bagov, P.M., B.Kh. Balkarov, T.Kh. Kuaševa, M.A. Kumakhov \& G.D. Rogava (eds.). 1970. Grammatika kabardino-čerkesskogo literaturnogo jazyka. čast’ 1. Fonetika i morphologija. [Grammar of the Standard Kabardian language. Part 1. Phonetics and morphology]. Nauka.

Comrie, Bernard. 1989. Language universals and linguistic typology, $2^{\text {nd }} e d$. The University of Chicago Press. doi:10.1525/aa.1982.84.4.02a00590.

Condoravdi, Cleo \& Sven Lauer. 2012. Imperatives: meaning and illocutionary force. In Empirical Issues in Syntax and Semantics 9, Papers from the Colloque de Syntaxe et S'emantique ‘a Paris, 37-58. http://www.cssp.cnrs.fr/eiss9/eiss9_condoravdi-and-lauer.pdf.

Giannakidou, Anastasia. 1998. Polarity sensitivity as (non)veridical dependency. John Benjamins. doi:10.1075/la.23.

Grohmann, Kleanthes. 2003. Prolific domains: On the anti-locality of movement. John Benjamins. doi:10.1075/la.66.

Gusev, V.Yu. 2005. Tipologija specializirovannyx glagol'nyx form imperativa: Institute of Linguistics, Russian Academy of Sciences dissertation.

Han, Chung-Hye. 1998. The structure and interpretation of imperatives: mood and force in universal grammar: University of Pennsylvania dissertation. http://repository. upenn.edu/dissertations/AAI9913465/. 
Harley, Heidi. 2011. A minimalist approach to argument structure. In Cedric Boeckx (ed.), The Oxford Handbook of Linguistic Minimalism, 427-448. OUP. doi:10.1093/oxfordhb/ 9780199549368.013.0019.

Heim, Irene. 2000. Degree operators and scope. In Brendan Jackson \& Tanya Matthews (eds.), Proceedings of SALT 10, 40-64. doi:http://dx.doi.org/10.3765/salt.v10i0.3102.

Kaufmann, Magdalena. 2012. Interpreting Imperatives, vol. 88 Studies in Linguistics and Philosophy. Springer. doi:10.1007/978-94-007-2269-9.

Kiparsky, Paul. 2013. Towards a null theory of the passive. Lingua 125(1). 7-33. doi:https: //doi.org/10.1016/j.lingua.2012.09.003.

Klimenchenko, Ljubov. 2014. Adverbial expressions in Besleney Kabardian [in Russian]: RSUH MA thesis.

Kumakhov, M.A. (ed.). 2006. Kabardino-čerkesskij jazyk [Kabardian language], vol. 1. El-Fa Publ.

Landau, Idan. 2010. The explicit syntax of implicit arguments. Linguistic Inquiry 31(3). 357388. doi:10.1162/LING_a_00001.

Legate, Julie Anne. 2008. Morphological and abstract case. Linguistic Inquiry 39(1). 55-101. doi:10.1162/ling.2008.39.1.55.

Legate, Julie Anne. 2014. Voice and v: Lessons from Acehnese. MIT Press. doi:https://doi.org/ 10.7551/mitpress/9780262028141.001.0001.

Letuchiy, Alexander. 2009. Kauzativ, dekauzativ i labil'nost' [Causative, anticausative and lability]. In Ya. G. Testelets (ed.), Aspekty polisintetizma: Očerki po grammatike adygejskogo jazyka [Aspects of polysynthesis: Sketches on the grammar of Adyghe], 372-428. Moscow: RGGU.

Levin, Beth \& Malka Rappoport Hovav. 1994. Unaccusativity: At the syntax-semantics interface. MIT Press.

Perlmutter, David. 1978. Impersonal passives and the unaccusative hypothesis. In Proceedings of the annual meeting of the Berkeley Linguistics Society, 157-189. doi:http://dx.doi.org/10. 3765/bls.v4i0.2198.

Portner, Paul. 2016. Imperatives. In Maria Aloni \& Paul Dekker (eds.), The Cambridge handbook of formal semantics, 593-626. Cambridge University Press. doi:https://doi.org/10.1017/ CBO9781139236157.021.

Pylkkänen, Liina. 2008. Introducing Arguments, vol. 49 Linguistic Inquiry Monographs. MIT Press. doi:10.7551/mitpress/9780262162548.001.0001.

Rivero, María Luisa \& Arhonto Terzi. 1995. Imperatives, V-movement and logical mood. Journal of Linguistics 31(2). 301-332. doi:https://doi.org/10.1017/S0022226700015620.

Rizzi, Luigi. 1997. The fine structure of the left periphery. In Liliane Haegeman (ed.), Elements of grammar: Handbook of generative syntax, 281-337. Kluwer Academic Publishers. doi: 10.1007/978-94-011-5420-8_7.

Rochant, Neige. 2015. Kauzativnyj marker v kubanskom dialekte kabardino-čerkesskogo jazyka [The causative marker in the Kuban dialect of Kabardian]. Expedition Report.

Roeper, Thomas. 1987. Implicit arguments and the head-complement relation. Linguistic Inquiry 18(2). 267-310. http: / /www. jstor.org/stable/4178538.

Sichel, Ivy. 2009. New evidence for the structural realization of the implicit external argument in nominalizations. Linguistic Inquiry 40/4. 712-723. 
Woolford, Ellen. 2006. Lexical case, inherent case, and argument structure. Linguistic Inquiry 37/1. 111-130. doi:10.1162/002438906775321175.

Xrakovskij, Viktor S. 2001. Hortative constructions. In Martin Haspelmath (ed.), Language typology and linguistic universals: An international handbook, vol. 2, 1028-1037. De Gruyter Mouton. doi:https://doi.org/10.1515/9783110171549.2.10.1028.

Zanuttini, Raffaella. 1997. Negation and clausal structure: A comparative study of Romance languages. Oxford University Press.

Zanuttini, Raffaella, Miok Pak \& Paul Portner. 2012. A syntactic analysis of interpretive restrictions on imperative, promissive and exhortative subjects. NLLT 30/4. 1231-1274. doi: 10.1007/s11049-012-9176-2.

Zeijlstra, Hedde. 2006. The ban on true negative imperatives. Empirical Issues in Syntax and Semantics 6. 405-424. http://hdl. handle. net/11245/1.267818. 